\title{
THE URBAN HEAT ISLAND OF PORTO ALEGRE, RS, SOUTHERN BRAZIL: AN ANALYSIS BETWEEN 1985 AND 2019 THROUGH THE RADIATIVE TRANSFER IN THE INFRARED THERMAL.
}

\author{
E. A. Kaiser ${ }^{1}$, R. de M. Linn $^{2}$, S. B. A. Rolim ${ }^{3}$, P. S. Käfer ${ }^{3}$, N. S. da Rocha ${ }^{3}$, L. R. Diaz ${ }^{3}$, A. Grondona ${ }^{4}$, S. T. L. Costa ${ }^{3}$, \\ G. P. Hallal ${ }^{3}$ \\ ${ }^{1}$ Centro Estadual de Pesquisas em Sensoriamento Remoto e Meteorologia, Universidade Federal do Rio Grande do Sul, Rio Grande \\ do Sul, Brazil - kaiser-eduardo@ hotmail.com \\ ${ }^{2}$ Secretaria Municipal do Meio Ambiente e da Sustentabilidade (SMAMS), Prefeitura Municipal de Porto Alegre, RS, Brazil - \\ rodrigoml@portoalegre.rs.gov.br \\ ${ }^{3}$ Centro Estadual de Pesquisas em Sensoriamento Remoto e Meteorologia, Universidade Federal do Rio Grande do Sul, Rio Grande \\ do Sul, Brazil- (silvia.rolim, najila.rocha, lucas.diaz)@ufrgs.br, (pamelaskafer, savannahlemos95, gabrielhallal)@gmail.com, \\ ${ }^{4}$ Universidade do Vale dos Sinos (UNISINOS) -Programa de graduação em Engenharia Civil, São Leopoldo, RS, Brazil, - \\ atilio.grondona@ufrgs.br
}

KEY WORDS: Urban Heat Island, Thermal, Land Use and Land Cover, Landsat.

\begin{abstract}
:
The objective of this study was to verify the evolution of surface temperature associated with land use and land cover from 1985 to 2019 in Porto Alegre, RS, Brazil. The methodological procedures were performed in five steps: 1. Definition of the study area; 2. Land use and land cover classification from images of Landsat 5 satellite Thematic Mapper (TM) and Operational Land Imager (OLI) from Landsat 8 satellite; 3. Calculation of surface temperature from TM sensor band 6 and OLI sensor band 10; 4. Analysis of temperature evolution over the historical series; and 5. Temporal relation between surface temperature and land use and land cover classes. The results demonstrated that higher temperatures were associated to the evolution of two classes of land use and land cover: urban area and exposed soil, with the former occupying 31\% in 1989 to $75 \%$ in 2018 of the study area. When comparing the first and last decade of the historical series for each season, there was an average increase of $4.18{ }^{\circ} \mathrm{C}$ in the surface temperature of the districts. Thus, adopting policies that mitigate the effects caused by densification and urban sprawl are necessary, mainly through the conservation of vegetated areas and water reservoirs, as these are crucial for the maintenance of air humidity and evapotranspiration.
\end{abstract}

\section{INTRODUCTION}

Given the process of urbanization, intensified from the eighteenth century and mainly linked to the occurrence of rural exodus and industrialization, one can observe the unbridled growth of population and urban areas.

The rural exodus entailed decreased rural population and the growth of the urban population. Currently the urban world population is larger than the rural population according to the World Urbanization Prospects (2014) report, developed by the United Nations Division for the Department of Economic and Social Affairs (DESA). In 2007, the urban population exceeded the rural population for the first time in history, remaining predominantly urban thereafter.

The expansion of cities severely alters the natural biophysical environment. The removal of vegetation cover for performing urban activities causes changes in the hydrological cycle and especially in the energy balance. Therefore, there are changes in air temperature and humidity, wind speed and direction. In addition, the city develops its own urban climate justified by these changes, the regional climate and the local physical environment (OKE, 1987; ANDRADE, 2005).

One of the main implications of the urbanization process is the increase in surface temperature and the consequent formation of the Urban Heat Island (UHI), also known as heat nucleus, thermal or humid nuclei and heated nucleus (MENDONÇA, 2003; ASSIS, 2010; FIALHO, 2012). This increase occurs due to anthropogenic interference with the environment by covering the surface with materials with high heating capacity (thermal inertia) and reducing green areas responsible for reducing surface temperature through evapotranspiration.

With increased population, urban sprawl (WILLIAM BURKEY, 2014) and the diversification of human activities, the management of large cities became one of the greatest challenges of the 21 st century. Planning and managing land use and occupation, water and sewerage infrastructure, public street lighting, paving, health, education and safety services, demand from the municipal governments and the municipal staff, enormous planning and management capacity. Although most large urban centers have bodies responsible for urban planning and the maintenance of public services, many lack data and information to support decision-making, enabling transparency of public actions and making available to the public enough information to actively exercise their rights of democratic participation in municipal administration matters.

Remote sensing techniques emerge to observe and model land surface biophysical properties. Several studies on the thermal characterization of urban surfaces from sensor data can be observed in the world literature, including Voogt and Oke (1997), Oke (2003), Jesen (2009) and Weng (2010 and 2003), El Magd et al. (2016), Keeratikasikorn \& Bonafoni (2018), Dissanayake, et al. (2019). In Brazil, the researches of Lombardo (1985), Coelho and Correa (2013), Teixeira and Amorim (2017), Romero et al. (2019) are emphasized among others.

The advent of remote sensing technology enabled the study of UHI both locally and globally, allowing the transformation of data in the thermal infrared spectral range into apparent surface 
temperature. According to Weng (2013), the temperature measured by remote sensing is the radiant surface temperature, whose quantification represents more meaningful value than the air temperature. This permits to qualify the temperature and therefore the heat island locally.

Over the last decades, Porto Alegre has experienced rapid urban growth, becoming a regional economic and population center. The rapid transformation and expansion of urban sprawl caused the densification of the central and rural areas and the phenomenon of urban conurbation. Thus, the impacts result in the continuous intensification of the UHI, reducing the indices that determine the quality of life of the population and hindering mitigation and urban planning actions by government agencies.

In a previous study on the development of heat islands in the municipality of Porto Alegre, Grondona et al., (2013) established a temporal qualitative analysis of two decades from the use of images displayed by orbital sensors. The results point to an increase in urban areas $(24.22 \%)$ and a reduction in vegetative areas $(4.13 \%)$, characterizing the increase in surface temperature from $24^{\circ} \mathrm{C}$ to $31^{\circ} \mathrm{C}$ in some areas, during the period .

Given the above, the objective of this study was to verify the evolution of surface temperature associated with land use and land cover from 1985 to 2019 in Porto Alegre, RS, Brazil.

\section{MATERIALS AND METHODS}

The study area of our research comprises the current urban area belonging to three districts located in Porto Alegre: Aberta dos Morros, Hípica and Restinga, State of Rio Grande do Sul, Brazil. This site covers an area of 47,630 hectares and is inserted in the geomorphological units of the Rio Grande Shield and the Central Depression, besides being influenced by the Coastal Plains (Vieira, 1984).

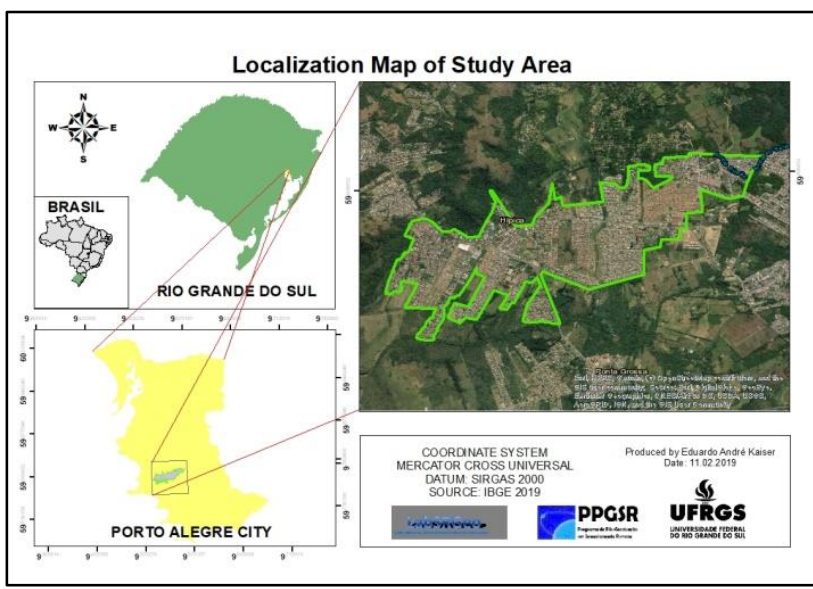

Figure 1. Location map of the urban area of districts Aberta dos Morros, Hípica and Restinga in the municipality of Porto Alegre, Rio Grande do Sul, Brazil.

According to Köppen climate classification, the climate of Porto Alegre belongs to the subtype "Cfa", with mean annual temperature of $19.5{ }^{\circ} \mathrm{C}$ and annual rainfall of $1300 \mathrm{~mm}$ (Ferraro, 1995).

The methodological procedures were performed in five steps: 1 . Definition of the study area; 2. Land use and land cover classification from images of Landsat 5 satellite Thematic Mapper (TM) and Operational Land Imager (OLI) from Landsat 8 satellite; 3. Calculation of surface temperature from TM sensor band 6 and OLI sensor band 10;4. Analysis of temperature evolution over the historical series; and 5 . Temporal relation between surface temperature and land use and land cover classes.

The definition of the study area was based on the occurrence of the urbanization process, i.e., the evolution of an urban area from 1985 to 2019. Therefore, an area with low predominance of anthropic materials from an image was searched based on satellite imagery corresponding to 1985 and which preferably had full coverage of this material in 2019.

Land use and land cover classification were based on images from the TM-Landsat 5 sensor and the OLI-Landsat 8 sensor referring to four dates of the 34-year historical series studied: 29/Sep/1989, 25/Sep/1999, 03/Oct/2008 and 16/Nov/2018. The definition of dates considered the approximate range of 10 years, availability of cloudless images and the associated seasonality, in this case the spring season. The software used comprised version 5.3 of Environment for Visualizing Images (ENVI), where the Maximum Likelihood supervised classification was performed. The land use and land cover classes used comprised those visually verified over the study area: Forest, Urban Area, Grass Field and Exposed Soil.

Land Surface temperature (LST) calculation was performed as described by Liu and Zhang (2011). According to the authors, the first step consists in converting the digital number of each pixel of the image into spectral radiance and converting it to brightness temperature from the Plank's function. The surface emissivity is calculated using the Normalized Difference Vegetation Index (NDVI). Such an index is calculated by Equation 1.

$$
N D V I=\frac{N I R-R}{N I R+R}
$$

where $\quad N D V I=$ Normalized Difference Vegetation Index NIR $=$ Near Infrared $\mathrm{R}=\mathrm{Red}$

Once NDVI values are obtained, emissivity is estimated through the intervals presented in Table 1, as proposed by Zhang et al. (2006).

\begin{tabular}{|l|l|}
\hline NDVI & Land surface emissivity $\left(\boldsymbol{\varepsilon}_{\mathrm{i}}\right)$ \\
\hline NDVI $<-0.185$ & 0.995 \\
\hline$-0.185 \leq \mathrm{NDVI}<0.157$ & 0.970 \\
\hline $0.157 \leq \mathrm{NDVI} \leq 0.727$ & $1.0094+0.047 \ln (\mathrm{NDVI})$ \\
\hline NDVI $>0.727$ & 0.990 \\
\hline
\end{tabular}

Table 1. Relation between the Normalized Difference Vegetation Index and the Emissivity proposed by Zhang et al. (2006).

Since the surface of Earth is not a perfect blackbody for thermal emission, the LST recovery from thermal radiation observed in space presents some complexity. In addition, the effects of atmosphere and soil should be considered ( $\mathrm{Li}$ et al. 2013; Wang et al. 2015). Therefore, to recover the LST, the Radioactive Transfer Equation (RTE) is applied to a sensor channel and wavelength range according to:

$$
L_{\text {sensor }, \lambda}=\left[\varepsilon_{\lambda} B_{\lambda}\left(T_{s}\right)+\left(1-\varepsilon_{\lambda}\right) L_{\lambda}^{\downarrow}\right] r_{\lambda}+L_{\lambda}^{\uparrow}
$$


where $\quad \mathrm{L}_{\text {sensor }}=$ at-sensor radiance in $\mathrm{Wm}^{-2} \mu \mathrm{m}^{-1} \mathrm{sr}^{-1}$

$\varepsilon=$ land surface emissivity (LSE)

$\mathrm{B}_{\lambda}\left(\mathrm{T}_{\mathrm{s}}\right)=$ Planck's law given by Equation (3)

$\mu \mathrm{m}^{-1} \mathrm{sr}^{-1}$

$\mathrm{L}^{\downarrow}=$ downwelling atmospheric radiance in $\mathrm{W} / \mathrm{m}^{-2}$ $\mu \mathrm{m}^{-1} \mathrm{sr}^{-1}$

$\mathrm{L}^{\uparrow}=$ the upwelling atmospheric radiance in $\mathrm{W} / \mathrm{m}^{-2}$ $\tau=$ atmospheric transmissivity

$$
B_{\lambda}\left(T_{S}\right)=\frac{C 1 \lambda^{-5}}{\exp (C 2 / \lambda \mathrm{T})-1}
$$

where

$$
\mathrm{C} 1=1.191 \times 10^{8} \mathrm{~W} \mu \mathrm{m}^{4} \mathrm{sr}^{-1} \mathrm{~m}^{-2}
$$$$
\mathrm{C} 2=1.439 \times 10^{4} \mu \mathrm{m} \mathrm{K} \text {. }
$$

Data were divided by season to verify the evolution of the surface temperature over the historical series. Thus, under similar weather conditions, data were grouped and compared using descriptive statistical analysis performed by parameters mean and standard deviation. From the surface temperatures obtained in each of the 117 images, the parameters were then calculated by year and respective season. We highlight that there were no images in some seasons, mainly due to the presence of cloudiness and/or technical failure in data collection by the sensor.

Lastly, the evolution of surface temperature associated with land use changes that occurred during the period from 1985 to 2019 in the study area was verified. Mean temperatures for each land use class and land cover were calculated according to its coverage area on the different dates.

\section{RESULTS AND DISCUSSION}

From the historical series of land use and land cover maps, significant changes were observed in the area occupied mainly by the urban area (Figure 2). In 1989, the total area corresponding to urban settlements was approximately 165 hectares, i.e., $31 \%$ of the study area and $75 \%$ in 2018 (397.6 hectares). We highlight the most significant variations of this class in the period from 1999 to 2008 , where its coverage increased $21.56 \%$ compared to $13.11 \%$ between 1989 and 1999 and $9.20 \%$ between 2008 and 2018 .

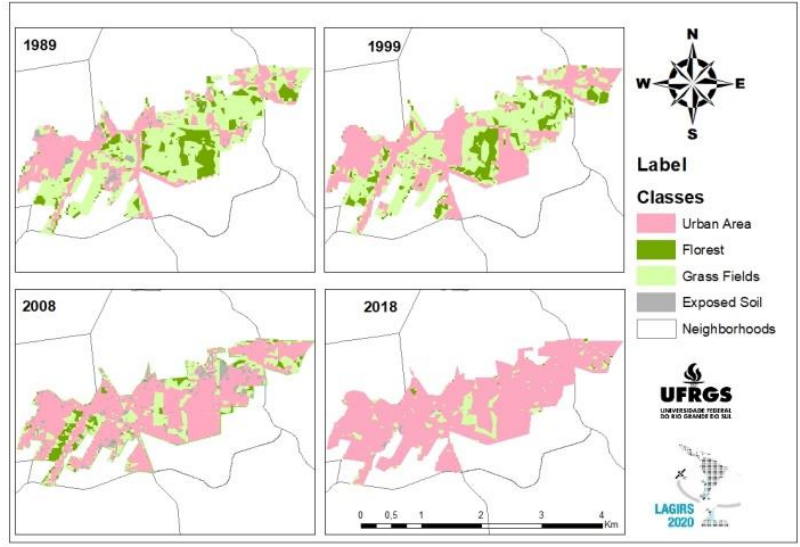

Figure 2. Maps of land use and coverage of 1989, 1999, 2008 and 2018 of the study area.

In turn, the land use and land cover classes designated as forest and grass fields decreased in their areas of occupation. In 1989 the forested areas occupied $14.44 \%$ of the area and they went to only $0.3 \%$ in 2018 , just as the grass field areas decreased from approximately $50 \%$ to $11 \%$ in the same period. These findings were directly associated with the urban sprawl expansion process, which according to Figure 2 demonstrates its evolution over areas previously covered by native forest, reforestation areas and grass fields.

The areas corresponding to the exposed soil class, as well as the urbanized areas exhibited increased occupation in the studied period. In 1989 they covered an area of approximately 19ha to 74.4 ha in 2018 , an increase from $3.5 \%$ to $14 \%$ of the total area. We emphasize the decrease of exposed soil areas from 1989 to 1999, whose difference was $3.3 \%$, possibly associated with the expansion of urbanized areas, since during this period it increased $142.4 \%$.

Once associated with land use and land cover maps (Figure 2), the calculated surface temperature means for exposed land cover and urbanized area were higher in all years when compared to forest and grass field cover. In the four classified images (Figure 3), minimum and maximum mean surface temperature differences respectively of $3.7^{\circ} \mathrm{C}$ in 1989 and 4.5 ${ }^{\circ} \mathrm{C}$ in 2008 were found between forest and urban area coverings. Even greater differences can be seen between the exposed soil and forest classes, whose smallest difference reached $3.6{ }^{\circ} \mathrm{C}$ in 2008 and $5.6{ }^{\circ} \mathrm{C}$ in 2018.

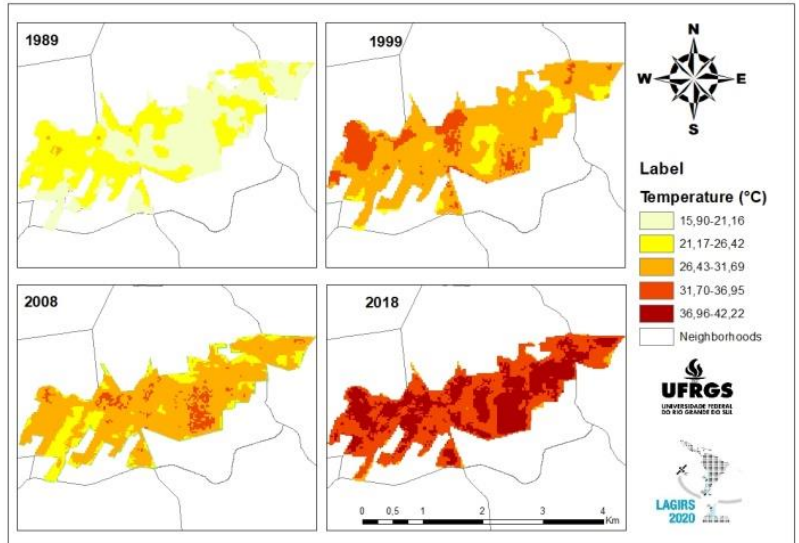

Figure 3. Surface temperature maps from October 1989, September 1999, October 2008, and November 2018.

Higher temperatures were associated with the evolution of two classes of land use and land cover: urban area and exposed soil. The latter is justified by the high thermal amplitude observed in this type of cover, which according to Mashiki (2012) exhibits significant variation in surface temperature over a short period of time. Thus, due to long periods of surface exposure to sunlight the temperature tends to rise sharply, intensifying the process of heat radiation to the environment.

Evident increase in temperature over the years analyzed is observed from the surface temperature maps of Figure 3 and the trend lines observed in the graphs of Figure 4. Seasonally, more perceptive variations could be observed in the fall season justified by the trend line of the data, whose difference between the mean temperatures observed between 1985-1995 (average of $20.82{ }^{\circ} \mathrm{C}$ over the ten years) and $2008-2018$ (average $27.03{ }^{\circ} \mathrm{C}$ ) was of $6.21{ }^{\circ} \mathrm{C}$. This difference was then $3.98{ }^{\circ} \mathrm{C}$ over summer, $3.39{ }^{\circ} \mathrm{C}$ in spring and $3.14^{\circ} \mathrm{C}$ in winter for the same periods. 


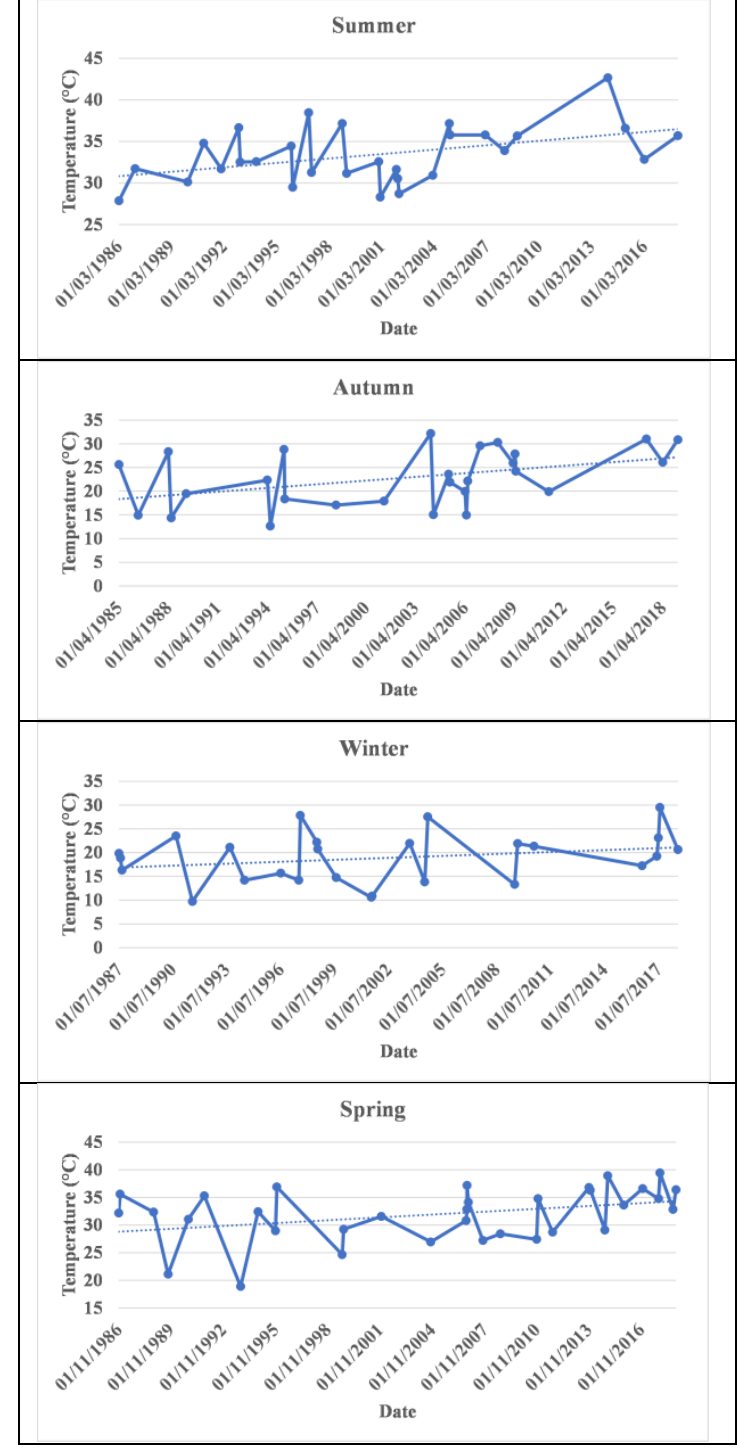

Figure 4. Surface temperature variations by season from 1985 to 2019 obtained from the mean temperature of the entire study area.

\section{CONCLUSIONS}

From 1989 to 2018 the current urban area belonging to the Aberta dos Morros (urban east side portion), Hípica (total urban portion) and Restinga (urban west side portion) districts underwent significant changes in their use and land cover. The forest and grass field classes decreased by approximately $98 \%$ and $79 \%$ respectively in their areas, while the classes represented by urban areas and surface exposure areas increased respectively from $31 \%$ and $3.5 \%$ in 1989 to $75 \%$ and $14 \%$ in 2018 of the study area.

The study allowed to demonstrate the influence of the process of urbanization and removal of vegetation cover on the increase of temperature. High surface temperatures were associated with areas of high urban concentration for both images classified in 1989 and 2018 but an average increase of $4.18{ }^{\circ} \mathrm{C}$ was observed when compared to the first and last decade of the historical series in the four seasons. This finding is attributed to the significant expansion of urban sprawl and exposed soil areas over forest and grass field areas. Thus, the interference of the characteristics of the surface covering materials is evident on the heat of the environment where they are located.

Increased temperature for each season during the period 1985 to 2019 is in line with the scenario projected by the Intergovernmental Panel on Climate Change (IPCC) in its Fifth Assessment Report (AR5). According to the report, by the end of the century the mean temperature increase should be from 2.6 to $4.8{ }^{\circ} \mathrm{C}$, mainly attributed to the growth of cities and their emission of $40 \%$ of the greenhouse gases (Rosenzweig et al., 2011; ECF, 2014).

Thus, the adoption of policies that mitigate the effects caused by urban densification and expansion is necessary, especially through the conservation of vegetated areas and water reservoirs, as these are of fundamental importance for the maintenance of air humidity and evapotranspiration.

Lastly, the information presented on surface temperature, land use and ground coverage through remote sensing techniques, using visible and infrared thermal bands from TM and OLI sensors respectively from Landsat 5 and 8 satellites allowed the visualization and comprehension of the microclimatic dynamics of an urban area in the city of Porto Alegre, RS, Brazil during the studied period, as well as its relation with the different types of surface coverage. Thus, we demonstrated a useful tool for implementing measures and guidelines that address urban and environmental planning and the appropriate use of geographic space in both the short and long term.

\section{ACKNOWLEDGEMENTS}

We thank the Coordination for Improvement of Higher Education Personnel (CAPES) for granting a scholarship to the first author.

\section{REFERENCES}

Andrade, H. O clima urbano: Natureza, escalas de análise e aplicabilidade. Finisterra, Lisboa, v. 50, n. 80, pp. 67-91, 2005.

Assis, W. L.: O sistema clima urbano do município de Belo Horizonte na perspectiva têmporo-espacial. Tese (Doutorado em Geografia) - Instituto de Geociências, Universidade Federal de Minas Gerais, Belo Horizonte, 2010, 299f.

Coelho, A.L.N; Correa, W.S.C. Temperatura de superfície celsius do sensor tirs/landsat-8: metodologia e aplicações. Revista Geográfica Acadêmica. Boa Vista: v. 7, n.1 p. 31-45, 2013.

Dissanayake, D. M. S. L. B., Morimoto, T., Ranagalage, M., \& Murayama, Y. (2019). Land-use/land-cover changes and their impact on surface urban heat islands: Case study of Kandy City, Sri Lanka. Climate, 7(8), 99.

ECF, 2014: Climate Change: Implications for cities. European Climate Foundation (ECF). Disponível em: $<$ http://www.iclei.org/fileadmin/ PUBLICATIONS/Brochures/IPCC_AR5_Cities_Summary_FI NAL_Web.pdf >. Acesso em: Setembro/2016.

El-Magd, I. A., Ismail, A., \& Zanaty, N. (2016). Spatial variability of urban heat islands in Cairo City, Egypt using time series of Landsat Satellite images. Int. J. Adv. Remote Sens. GIS, 5, 1618 . 
Ferraro L.W., H. H. Avaliação das variáveis climáticas de superfície do baixo jacuí, rs. Porto Alegre: UFRGS/Centro de Ecologia- (Progress Report, 6), p. 47, 1995.

Fialho, E. S. Ilha de calor em cidade de pequeno porte: Caso de Viçosa, na Zona da Mata Mineira. Tese (Doutorado em Geografia Física), Faculdade de Filosofia, Letras e Ciências Humanas, Universidade de São Paulo, São Paulo, 2009, 248f. Ilha de Calor: Reflexões acerca de um conceito. ACTA Geográfica, Boa Vista, Ed. Esp. Climatologia Geográfica, 2012. pp.61-76.

Bica Grondona, A. E., Veettil, B. K., \& Alves Rolim, S. B. (2013). Urban heat island development during the last two decades in Porto Alegre, Brazil and its monitoring. Joint Urban Remote Sensing Event 2013. doi:10.1109/jurse.2013.6550666.

Keeratikasikorn, C., \& Bonafoni, S. (2018). Urban heat island analysis over the land use zoning plan of Bangkok by means of Landsat 8 imagery. Remote Sensing, 10(3), 440.

Lombardo, M. A. Ilha de calor nas metrópoles: o exemplo de São Paulo. São Paulo: Hucitec, 1985. 244p.

Mashiki, M. Y. Geoprocessamento na identificação de ilhas de calor e infuência do uso e ocupação do solo na temperatura aparente da superfície no município de Botucatu/SP. 2012. Dissertação (Mestrado em Agronomia) -Faculdade de Ciências Agronômicas, Universidade Estadual de São Paulo, Botucatu, 2012. Teoria e clima urbano - um projeto e seus caminhos. In: Monteiro, C. A. F; Mendonça, F. (Org.). Clima urbano. São Paulo: Contexto, p. 9-67, 2003.

Oke, T. R.: Boundary Layer Climates. Londres: Routledge, $2^{\mathrm{a}}$ ed. 435 p., 1987.

Romero, M. A. B., Baptista, G. M. D. M., Lima, E. A. D., Werneck, D. R., Vianna, E. O., \& Sales, G. D. L. Mudanças climáticas e ilhas de calor urbanas. Brasília: Universidade de Brasília, Faculdade de Arquitetura e Urbanismo; ETB, 2019. DOI: http://dx.doi.org/10.18830/ISBN.978-85-67405-25-4.

Rosenzweig, C. et al., 2011: Urban Climate Change in Context. Climate Change and Cities: First Assessment Report of the Urban Climate Change Research Network, C. Rosenzweig, W. D. Solecki, S. A. Hammer, S. Mehrotra, Eds., Cambridge University Press, Cambridge, UK, 3-11.

Teixeira, D. C. F., \& Amorim, M. C. D. C. T. (2017). Ilhas de calor: representações espaciais de cidades de pequeno porte por meio de modelagem. GEOUSP: Espaço E Tempo (Online), 21(1), 239-256.

\section{UNITED NATIONS, DEPARTMENT OF ECONOMIC AND} SOCIAL AFFAIRS, Population Department. World Urbanization Prospects. United Nations, [s. 1.], v. 12, p. 32, 2014.

Burkey, W. Urban Sprawl. 2014. Disponível em: $<$ https://academic-eb-

britannica.ez45.periodicos.capes.gov.br/levels/collegiate/article/ urban-sprawl/475347>. Acesso em: 14 nov. 2019.

Vieira, E. Rio grande do Sul: geografia física e vegetação. Porto Alegre: Sagra, p. 256, 1984.
Zhang, Y. T. Yu, X-F. Gu, L-F. Chen. "Land Surface Temperature Retrieval from CBERS-02 IRMSS Thermal Infrared Data and Its Applications in Quantitative Analysis of Urban Heal Island Effect', Journal of Remote Sensing, Vol. 10, No. 5, pp. 789-797, 2006. 